\title{
In respond to commensal bacteria: $\gamma \delta T$ cells play a pleiotropic role in tumor immunity
}

\author{
Yongting Liu' ${ }^{1}$, Ying Han ${ }^{1,2}$, Shan Zeng ${ }^{1,2,3}$ and Hong Shen ${ }^{1,2,3^{*}}$ (1)
}

\begin{abstract}
$\gamma \delta T$ cells are a mixture of innate programming and acquired adaptability that bridge the adaptive and innate immune systems. $\gamma \delta T$ cells are mainly classified as tissue-resident $V \delta 1$ or circulating $V \delta 2 \gamma \delta T$ cells. In the tumor microenvironment, tumor immunity is influenced by the increased quantity and phenotype plasticity of $\gamma \delta T$ cells. Commensal bacteria are ubiquitous in the human body, and they have been confirmed to exist in various tumor tissues. With the participation of commensal bacteria, $\gamma \delta T$ cells maintain homeostasis and are activated to affect the development and progression of tumors. Here, we summarize the relationship between $\gamma \delta T$ cells and commensal bacteria, the potential protumor and antitumor effects underlying $\gamma \delta T$ cells, and the new developments in $\gamma \delta T$ cell-based tumor therapy which is expected to open new opportunities for tumor immunotherapy.
\end{abstract}

Keywords: $\ulcorner\delta$ T cells, Commensal bacteria, Protumor effects, Antitumor effects, Immunity therapy

\section{Background}

\section{Commensal bacteria}

The human body comprises $10 \%$ cells and $90 \%$ bacteria. These bacteria reside in the skin, gastrointestinal tract, breast, lung, urinary tract and other regions. They are collectively known as commensal bacteria and have a complex connection with tumor immunity in the body [1]. With the latest developments in 16S rRNA gene sequencing and metagenomic analysis, an increasing number of bacteria have been found in the tumor microenvironment (TME). In an experiment with more than 300 samples of 7 solid tumors the distribution of bacteria was tissue-specific and tumor sub-type specific. One thing in common was that Proteobacteria and Firmicutes phyla account for most of the detected bacterial species, but the ratio of Proteobacteria to Firmicutes seems to vary between tumor types [2].

Cancer patients experience an imbalanced microbiota state called "dysbiosis", which is reflected in a substantial

*Correspondence: hongshen2000@csu.edu.cn

1 Department of Oncology, Xiangya Hospital, Central South University, Changsha 410008, Hunan, China

Full list of author information is available at the end of the article reduction in bacterial diversity and community stability [3]. Independent of specific bacterial species, dysbiosis promotes the development and progression of tumors [4]. It is mediated by a decrease in tumor necrosis factor alpha (TNF- $\alpha$ ) levels in tissues and the blood circulation, leading to reduced expression of tumor endothelial adhesion molecules, especially intercellular adhesion molecule 1 (ICAM-1). The expression of ICAM-1 is reduced by more than $50 \%$, ultimately reducing the antitumor effect of $\mathrm{CD}^{+} \mathrm{T}$ cells $[5,6]$. Dysbiosis also affects the response to chemotherapy, including the traditional chemotherapeutic drug cyclophosphamide [7] and new immune checkpoint inhibitors $[8,9]$.

\section{ү $\delta \mathrm{T}$ cells}

$\gamma \delta \mathrm{T}$ cells are a mixture of innate programming and acquired adaptability that bridge the adaptive and innate immune systems $[10,11]$. They are mainly distributed in the skin and mucosal epithelium and account for the majority of tissue-resident $\mathrm{T}$ cells. In addition, $1-5 \%$ of $\gamma \delta \mathrm{T}$ cells are found in peripheral blood [12]. In terms of TCR $\delta$ chain usage, V $\delta 1 \mathrm{~T}$ cells are mainly located in the skin and mucous membranes and interact with $V \gamma 2$, $\gamma 3, \gamma 4, \gamma 5$ and $\gamma 8$ chains to maintain epithelial stability.

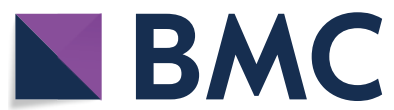

(c) The Author(s) 2021. This article is licensed under a Creative Commons Attribution 4.0 International License, which permits use, sharing, adaptation, distribution and reproduction in any medium or format, as long as you give appropriate credit to the original author(s) and the source, provide a link to the Creative Commons licence, and indicate if changes were made. The images or other third party material in this article are included in the article's Creative Commons licence, unless indicated otherwise in a credit line to the material. If material is not included in the article's Creative Commons licence and your intended use is not permitted by statutory regulation or exceeds the permitted use, you will need to obtain permission directly from the copyright holder. To view a copy of this licence, visit http://creativeco mmons.org/licenses/by/4.0/. The Creative Commons Public Domain Dedication waiver (http://creativecommons.org/publicdomain/ zero/1.0/) applies to the data made available in this article, unless otherwise stated in a credit line to the data. 
$\mathrm{V} \delta 2 \mathrm{~V} \gamma 9 \mathrm{~T}$ cells account for up to $90 \%$ of circulating $\gamma \delta \mathrm{T}$ cells and can be recruited to the corresponding tissues to perform their functions [13].

It is worth noting that there are some species heterogeneities in gene evolution of TCR between humans and mice. Mice $\gamma \delta$ T cells depends on the specific TCR $V_{\gamma}$ chain, $V_{\gamma} 1-7$. In spite of the discrepancy, $\gamma \delta \mathrm{T}$ cells have functional similarity in mice and humans [14].

Most $\gamma \delta \mathrm{T}$ cells are $\mathrm{CD}^{-}$and $\mathrm{CD} 8^{-}$cells, and their antigen recognition is not subject to major histocompatibility complex $(\mathrm{MHC})$ restriction. $\gamma \delta \mathrm{T}$ cells can also be activated by cytokines independent of their $\gamma \delta$ TCRs and take effect earlier. The activation, expansion, migration and functional plasticity of intratumor $\gamma \delta \mathrm{T}$ cells are driven by changes in the TME, and these properties have a significant impact on maintaining mucosal stability and tumor immunity $[13,15]$.

Here, we review the relationship between commensal bacteria and $\gamma \delta$ T cells as well as the mechanism behind the dual effects of $\gamma \delta \mathrm{T}$ cells on tumors harboring commensal bacteria. These findings are expected to identify new targets for tumor immunotherapy.

\section{Commensal bacteria participate in the homeostasis of $\gamma \delta T$ cells}

The homeostasis of $\gamma \delta \mathrm{T}$ cells is affected by commensal bacteria. In dysbiosis or germ-free (GF) mice, the number of $\gamma \delta \mathrm{T}$ cells is significantly reduced compared to that in their conventionally housed, specific pathogen-free (SPF) counterparts, as confirmed in the liver, lungs, intestines and peritoneum $[16,17]$. The intestinal mucosa can be used as an example. Under normal circumstances, $\gamma \delta \mathrm{T}$ cells rely on the communication between aryl hydrocarbon receptors (AhRs) and interleukin (IL)-15 produced by intestinal epithelial cells stimulated by microorganisms [18]. In GF models, Bifidobacteriaceae and Bacillaceae are positively related to intestinal $\gamma \delta \mathrm{T}$ cells, while bacteria belonging to the families Rhodospirillaceae, Flavobacteriaceae and Prevotellaceae have the opposite relationship [16]. In the liver, Escherichia coli (E. coli) transplantation can improve $\gamma \delta \mathrm{T}$ cell deficiency, but the Escherichia coli population is not irreplaceable [19]. Intraperitoneal injection of neomycin sulfate and vancomycin to kill facultative gram-positive and/or gram-negative organisms may result in lower numbers of $\gamma \delta \mathrm{T}$ cells in the peritoneum of the treated group than the control group. However, metronidazole treatment has no effect on the number of $\gamma \delta \mathrm{T}$ cells [20].

In general, there are few identified bacteria that are particularly relevant to $\gamma \delta$ T cells. In any case, stability of the commensal bacterial population is important for the homeostasis of $\gamma \delta \mathrm{T}$ cells.

\section{Commensal bacteria activate $\gamma \delta \mathrm{T}$ cells via different mechanisms}

The binding of bacterial pathogen-associated molecular patterns (PAMPs) to Toll-like receptors (TLRs) on $\gamma \delta \mathrm{T}$ cells exerts an activating effect through the myeloid differentiation factor 88 (MyD88) pathway [21]. Although the study on TLRs of human $\gamma \delta$ T cells is not sufficient, the current unified conclusion is that $\gamma \delta \mathrm{T}$ cells have TLR1 $\sim 8[21,22]$. The TLR2 and TLR5 can recognize lipopolysaccharide and flagellin, perceiving commensal bacteria. TLR3 mainly cooperates with TCR to play an antiviral effect [23]. The activation of TLR8 can reverse the immunosuppressive function of $\gamma \delta \mathrm{T}$ cells [24]. Other TLRs are poorly expressed and rarely studied. Moreover, phagocytes produce IL-1, an inflammatory factor whose production is stimulated by commensal bacteria. IL- 1 can be recognized by $\gamma \delta \mathrm{T}$ cells and function through an IL-1R-Vav guanine nucleotide exchange factor 1 (VAV1)-dependent mechanism [20]. V $\delta 1$ TCR has a special affinity for CD1-presented lipid sulfatide, modulated by the complementaritydetermining region 3 loop to discriminate different lipid antigens, especially intestinal $\gamma \delta \mathrm{T}$ cells $[25,26]$. Another study confirmed that $\gamma \delta \mathrm{T}$ cells in the liver but not the spleen are uniquely sensitive to lipid antigens derived from E. coli [27]. Phosphoantigens, such as bacterial lysate-derived (E)-4-hydroxy-3-methyl-but-2-enyl pyrophosphate (HMBPP), are also powerful stimulators of $\gamma \delta \mathrm{T}$ cells [28]. As the most potent phosphoantigen known to stimulate $\gamma \delta \mathrm{T}$ cells, HMBPP mainly activates circulating V $\delta 2 \mathrm{~V} \gamma 9 \mathrm{~T}$ cells [29]. HMBPP binding to intracellular domain of butyrophilin 3A1 (BTN3A1) leads to the extracellular detection by the $\mathrm{V} \delta 2 \mathrm{~V} \gamma 9$ $\mathrm{TCR}$, which reinforces the efficiency of $\gamma \delta \mathrm{T}$ cell activation [30, 31] (Table 1).

Table 1 $\gamma \delta$ T cells activation: ligands and receptors

\begin{tabular}{|c|c|c|c|}
\hline Source & Ligand & Receptor & References \\
\hline \multirow[t]{4}{*}{ Bacterial } & PAMP & $\mathrm{TLR} 2 / 5$ & {$[22]$} \\
\hline & $\mid \mathrm{L}-1$ & $\mathbb{I L}-1 \mathrm{R}$ & [20] \\
\hline & Lipid antigen-CD1d & V\&1TCR & {$[25,26]$} \\
\hline & HMBPP-BTN3A1 & Vঠ2TCR & {$[30,92]$} \\
\hline \multirow[t]{8}{*}{ Cancer cell } & MICA/B, ULBP & NKG2D & {$[55,57]$} \\
\hline & $\mathrm{hMSH} 2$ & NKG2D & [64] \\
\hline & Nectin-like 5 & DNAM-1 & {$[54]$} \\
\hline & $\mathrm{B} 7-\mathrm{H} 6$ & NKp30 & {$[59,60]$} \\
\hline & Not known & NKp46 & {$[58]$} \\
\hline & F1-ATPase & V $\delta 2 T C R$ & [61] \\
\hline & annexin $\mathrm{A} 2$ & V83TCR & {$[62]$} \\
\hline & IPP-BTN3A1 & V82TCR & {$[81,84]$} \\
\hline
\end{tabular}




\section{Commensal bacteria play an important role in the migration of $\gamma \delta \mathrm{T}$ cells}

Similar to $\alpha \beta T$ cells, $\gamma \delta \mathrm{T}$ cells are highly dynamic. Both tissue-resident and circulating $\gamma \delta \mathrm{T}$ cells can rapidly migrate and be recruited to the effector site. Many studies have focused on gut-resident cells. Epitheliummediated microbial sensing is part of an important mechanism [32]. $\gamma \delta$ T cells actively respond to bacterial signals and migrate from the basal to the apical surface of the epithelium, which is in direct contact with bacteria. This process occurs via a mechanism dependent on occluding, which is expressed by $\gamma \delta$ T cells [33, 34]. IL-15 is also engaged in that mechanism [35]. Vertical displacement of $\gamma \delta \mathrm{T}$ cells is reduced in mice devoid of a microbiota [36], which reemphasizes the importance of bacteria. In addition, V82T cells highly express C-X-C chemokine receptor 3 (CXCR3), C-C motif chemokine receptor 5 (CCR5) and, to a lesser extent, CCR2, guiding the recruitment of $\gamma \delta \mathrm{T}$ cells from blood to tissues [37].

\section{Classification of intratumoral $\gamma \delta T$ cells}

Hinging on the TME, $\gamma \delta$ T cells undergo functional plasticity and differentiate into different phenotypes [38]. The actions of $\gamma \delta \mathrm{T} 17$ cells are indispensable within the tumor and are the main producers of IL-17 in tumor tissues $[20,39,40]$. Unlike mice, there has been some evidence that human $\gamma \delta \mathrm{T} 17$ cells are not pre-programmed in the thymus, but acquire IL-17 expression bias from the periphery under the stimulation of stable commensal bacteria and the participation of many cytokines [41, 42]. Tumor-associated myeloid cells sense microbial stimulation via MyD88 and TIR-domain-containing adaptor inducing interferon- $\beta$ (TRIF) pathways and secrete IL-1 and IL-23, which are key inducers of $\gamma \delta \mathrm{T} 17$ cells $[43,44]$. In addition, IL-7 has been proven to be a more rapidly responsive IL-17 stimulator in solid tumors $[45,46]$. IL-7 preferentially activates STAT3 in $\gamma \delta \mathrm{T}$ cells rather than STAT5 in Th17 cells, significantly expanding the $\gamma \delta$ T17 cells, in both humans and mice [47]. Retinoic acid-related orphan nuclear receptor gamma $\mathrm{t}(\mathrm{ROR} \gamma \mathrm{t})$ is also related to the polarization of $\gamma \delta \mathrm{T} 17$ cells. This characteristic is specifically manifested as the induced expression of the gene encoding IL-17 by ROR $\gamma \mathrm{t}$ when $\gamma \delta \mathrm{T}$ cells are stimulated with transforming growth factors (TGF$\beta)$ and IL-6 [48]. TGF- $\beta$ also promotes the polarization of Foxp $3^{+}$regulatory $\gamma \delta \mathrm{T}(\gamma \delta \mathrm{Treg})$ cells with cooperation from IL-15 in vitro $[49,50]$. Cytotoxic helper $\gamma \delta \mathrm{T} 1$ $(\gamma \delta \mathrm{Th} 1)$ cells are also found in the TME and their properties are selectively acquired upon stimulation with IL-2 or IL-15 [51, 52] (Table 2).

\section{The dual effects of $\gamma \delta T$ cells on tumors Antitumor effect (Fig. 1)}

A meta-analysis of 18,000 human tumor samples clarified that intratumoral $\gamma \delta$ T cells participate in the formation of the most favorable cell population for cancer prognosis [53]. $\gamma \delta \mathrm{T}$ cells express multiple natural killer receptors, including natural killer, group 2, member $\mathrm{D}$ (NKG2D); the DNAX accessory molecule-1 (DNAM-1) receptor; and the natural cytotoxicity receptor (NCR) [54-56]. MHC class I-related chains A/B (MICA/B) and UL16-binding proteins (ULBP) are upregulated ligands in cancer cells that are recognized by NKG2D and exert cytotoxic effects in cooperation with $\gamma \delta \mathrm{TCR}[55,57]$. DNAM-1 and nectin-like-5 have been demonstrated to interact on $\mathrm{V} \delta 2 \mathrm{~V} \gamma 9 \mathrm{~T}$ cells in hepatocellular carcinoma [54]. NCRs, especially NKp46, which is negatively correlated with the risk of metastasis in colorectal cancer, are abundantly expressed on V81T cells [58]. The ligand for NKp30 on V81T cells is B7-H6, which is common in lymphoma and leukemia $[59,60]$ (Table 1).

In addition, tumor cells express a variety of specific surface proteins, which are of great significance to the functional activation of $\gamma \delta \mathrm{T}$ cells (Table 1 ). The mitochondrial F1-ATPase-related structure has been detected on the surface of tumor cells. With binding to the delipidated form of apolipoprotein A-I (apo A-I), F1-ATPase shows the characteristic of being actively recognized by $\mathrm{V} \delta 2 \mathrm{~V} \gamma \mathrm{9}$ TCR [61]. In recent years, annexin A2 was identified to be a ligand for V $\delta 3$ TCR [62]. Annexin A2 is a phospholipid-binding protein in the cytoplasm and is exposed on the membrane in response to oxidative stress [63]. In general, tumor-specific surface proteins could constitute danger signals for $\gamma \delta \mathrm{T}$ cells recognition, reducing the possibility of immune shielding.

Table 2 The phenotypes, stimulators and effects of intratumoral $\gamma \delta T$ cells

\begin{tabular}{|c|c|c|c|}
\hline Phenotype & Stimulator & Effect & References \\
\hline ү $\delta \mathrm{T} 17$ & IL-7; IL-1, IL-23; TGF- $\beta, ~ I L-6$ & $\begin{array}{l}\text { Recruit PMN-MDSC and TAN, increase VEGF, express anti- } \\
\text { apoptotic genes }\end{array}$ & {$[43,44,47,70,75]$} \\
\hline ү§Treg & TGF- $\beta, I L-15$ & Increase adenosine, inhibit $\gamma \delta T h 1$ & {$[49,80]$} \\
\hline$\gamma \delta T h 1$ & $\| \mathrm{L}-2, \mathrm{IL}-15$ & Secret IFN- $\gamma$ & {$[51,52]$} \\
\hline YST-APC & PAMP & $\begin{array}{l}\text { Regulate CD4+ or CD8+T cells, induce mucosa to } \\
\text { release calprotectin }\end{array}$ & {$[67,68]$} \\
\hline
\end{tabular}



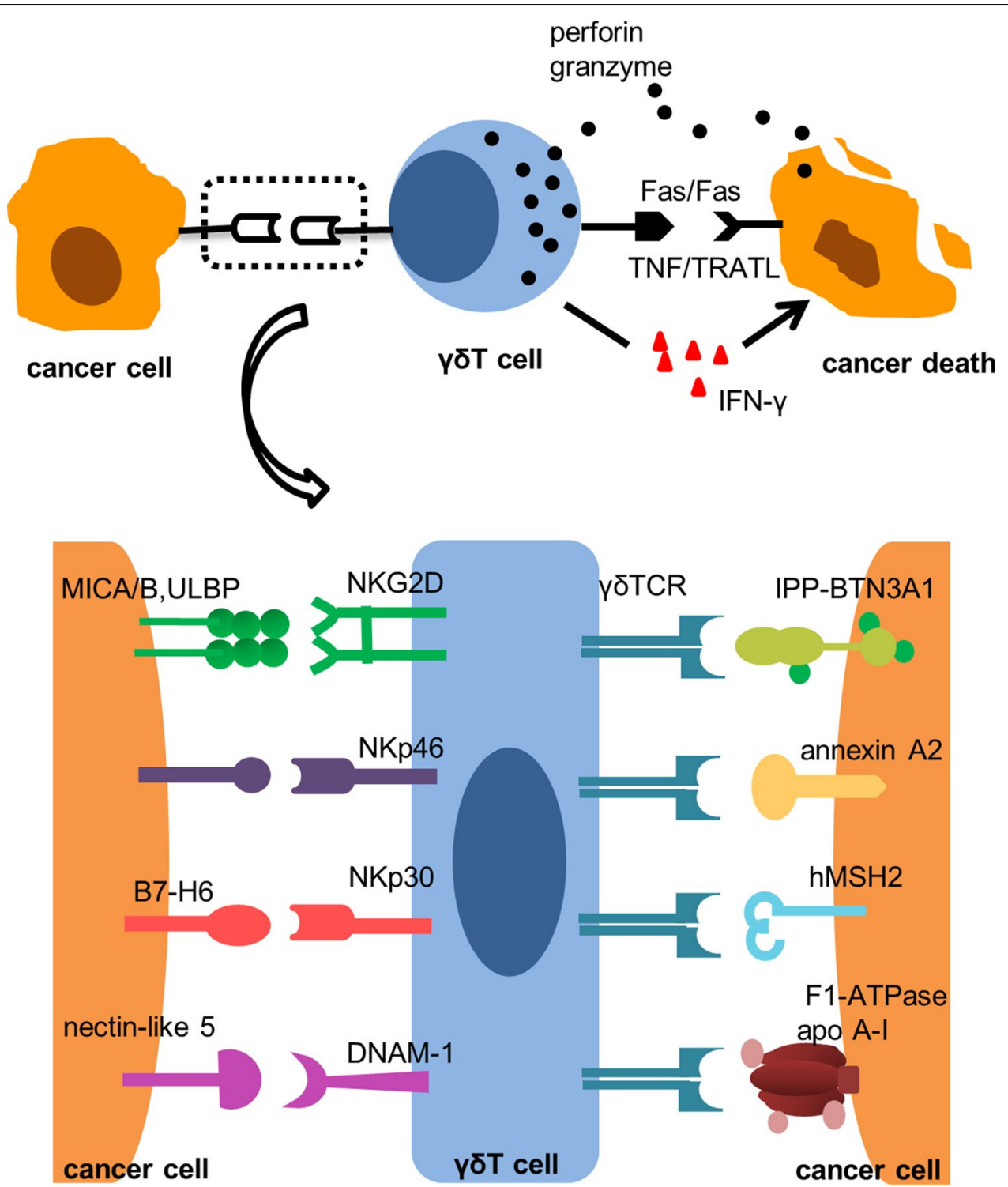

Fig. 1 Antitumor effects of $\gamma \delta T$ cells. $\gamma \delta T$ cells inhibit tumor growth through receptor-ligand interactions. MHC class I-related chains A/B (MICA/B) and UL16-binding protein (ULBP) are upregulated in cancer cells and are recognized by natural killer, group 2, member D (NKG2D), which exerts cytotoxic effects in cooperation with $\gamma \delta T C R$. DNAX accessory molecule-1 (DNAM-1) and nectin-like-5 have been proven to interact on V $82 \mathrm{~V} Y 9 T$ cells in hepatocellular carcinoma. Natural cytotoxicity receptors (NCRs), especially NKp46, which is negatively correlated with the risk of metastasis in colorectal cancer, are abundantly expressed on V $81 T$ cells. The ligand for NKp30 on V $81 T$ cells is B7-H6, which is common in lymphoma and leukemia. Tumor surface protein: hMSH2, F1-ATPase-related structure and annexin A2 could constitute danger signals for $\gamma \delta T$ cells recognition, reducing the possibility of immune shielding. Like natural killer cells, $\gamma \delta T$ cells kill cancer cells indirectly by releasing interferon-gamma (IFN- $\gamma$ ), thereby exhibiting a Th1 cell-like phenotype, or directly via the death receptor signal factor associated suicide ligand (FasL) and TNF-related apoptosis-inducing ligand (TRAIL), secreting cytotoxic molecules such as granzyme and perforin

Similar to natural killer cells, $\gamma \delta \mathrm{T}$ cells can kill cancer cells indirectly by releasing abundant amounts of interferon-gamma (IFN- $\gamma$ ) thereby displaying a Th1 cell-like phenotype. $\gamma \delta$ T cells can also kill cancer cells directly via the death receptor signal factor associated suicide ligand (FasL) and TNF-related apoptosis-inducing ligand (TRAIL), secreting cytotoxic molecules such as granzyme and perforin [54]. Human MutS homologue 2 (hMSH2) is an ectopic nuclear protein associated with a variety of epithelial tumor cells. Both $\gamma \delta$ TCR and NKG2D participate in the recognition of hMSH2, stimulating the proliferation of $\mathrm{V} \delta 2 \mathrm{~V} \gamma 9 \mathrm{~T}$ cells and enhancing IFN- $\gamma$ mediated antitumor activity [64]. In addition, an increase in the number of $V \delta 1 \mathrm{~T}$ cells expressing 
CCR2, which produce IFN- $\gamma$, has been observed in melanoma and hepatocellular carcinoma $[65,66] . \gamma \delta \mathrm{T}$ cells with antigen presentation function $(\gamma \delta \mathrm{T}-\mathrm{APCs}) \mathrm{regu}-$ late $\mathrm{CD}^{+}$or $\mathrm{CD}^{+} \mathrm{T}$ cells, which initiate the adaptive immune response [67]. $\gamma \delta \mathrm{T}-\mathrm{APC}$ induces the mucosa to secrete calprotectin, which plays a role in the defense against intestinal mucosal inflammation [68].

\section{Protumor effects (Fig. 2)}

$\gamma \delta \mathrm{T}$ cells exert unexpected protumor effects. The tumorpromoting functions are mainly due to IL-17-producing
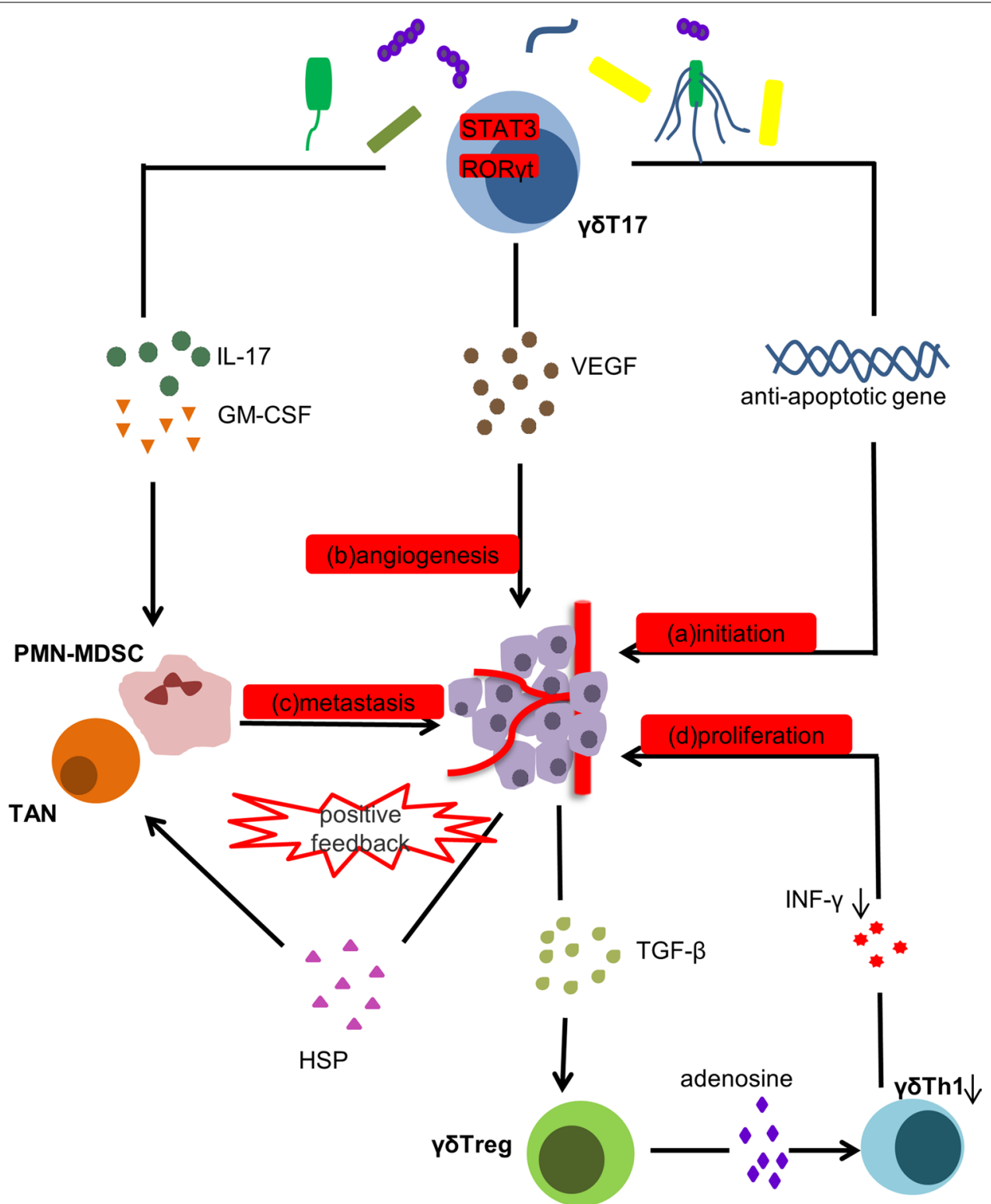

Fig. 2 Protumor effects of $\gamma \delta T$ cells. $ү \delta T$ cells are activated and recruited to tumor sites under stimulation by commensal bacteria. Signal transducer and activator of transcription 3 (STAT3) and orphan nuclear receptor gammat (RORүt) are essential transcription factors for $\gamma \delta T 17$ cells. a $\gamma \delta T 17$ cells express antiapoptotic genes, such as BCl-2, McL-1 and Survivin, promoting the growth of cells with tumorigenic potential and imparting the possibility for tumor initiation. b $\gamma \delta T 17$ cells increase the concentration of vascular endothelial growth factor (VEGF), which promotes tumor angiogenesis. c Secretion of IL-17 is accompanied by production of granulocyte-macrophage colony-stimulating factor (GM-CSF), leading to accumulation of polymorphonuclear myeloid-derived suppressor cells (PMN-MDSCs) and tumor-associated neutrophils (TANs), which is conducive to tumor metastasis. PMN-MDSCs can also sense heat shock proteins (HSPs) released by cancer cells and play a further immunosuppressive role. $d$ In addition, $\gamma \delta$ Tregs can inhibit the secretion of interferon $\gamma(I N F-\gamma)$ from $\gamma \delta$ Th 1 cells by increasing the amount of adenosine in the tumor microenvironment, resulting in excessive tumor proliferation 
$\gamma \delta \mathrm{T}$ cells. Current studies believe that tissue-resident V $\delta 1 \mathrm{~T}$ cells are more inclined to differentiate into $\gamma \delta \mathrm{T} 17$ cells, a finding seen in skin squamous cell carcinoma [69], colorectal cancer [70], breast cancer [71] and lung cancer [72]. Signal transducer and activator of transcription 3 (STAT3) is an indispensable transcription factor for IL-17 and it is also a target of antiapoptotic genes [73, 74]. The expression of genes such as Bcl-2, Mcl-1 and Survivin promotes the growth of cells with tumorigenic potential [74]. Secretion of IL-17 by $\gamma \delta$ T cells is accompanied by upregulation of the expression of granulocyte-macrophage colony-stimulating factor (GM-CSF), which leads to accumulation of polymorphonuclear myeloid-derived suppressor cells (PMN-MDSCs) [70] and tumor-associated neutrophils (TANs) [75] at tumor sites. Accumulation of PMN-MDSCs and TANs at tumor sites establishes an immunosuppressive network in the TME, such that local and distant tumor metastasis becomes possible [76]. Also, PMN-MDSCs respond to heat shock proteins (HSPs) in tumor exosomes to exert further immunosuppressive effects [77]. Furthermore, high expression of IL- 17 by $\gamma \delta \mathrm{T}$ cells is associated with a high microvessel density. IL-17 also increases the concentration of vascular endothelial growth factor (VEGF) to promote tumor angiogenesis and has a unique tumorpromoting effect in human colorectal [78] and gallbladder cancers [79].

The CD $39^{+} \gamma \delta$ T cells are a new type of $\gamma \delta$ Treg found in human colorectal cancer reported in 2020 by Hu et al. [80]. The phenotype of $\gamma \delta \mathrm{T}$ cells is plastic, such that it is normal for different types of $\gamma \delta \mathrm{T}$ cells to have functional crossover. CD $39^{+} \gamma \delta$ T cells express high levels of FOXP3 and secrete IL-17 and GM-CSF. In addition to attracting PMN-MDSCs, CD $39^{+} \gamma \delta$ Tregs can also inhibit the functions of $\gamma \delta$ Th 1 cells by increasing the concentration of adenosine in the TME, which allows cancer cells to further escape immune attack. Unexpectedly, CD39 ${ }^{+} \gamma \delta \mathrm{T}$ cells were found to exhibit more potent immunosuppressive activity than conventional CD4 ${ }^{+}$Tregs [80].

\section{Clinical implication}

At present, tumor therapy based on $\gamma \delta \mathrm{T}$ cells has received increasing attention, as a satisfactory response has been achieved in combination with chemotherapy and immunotherapy. Zoledronate can upregulate the expression of isopentenyl pyrophosphate (IPP) in cancer cells [81]. V $\delta 2 \mathrm{~V} \gamma 9 \mathrm{~T}$ cells exposed to a large number of phosphoantigens can rapidly develop amplified antigen sensitivity and tumor recognition [82, 83]. Solid cancer cells pretreated with low concentrations of zoledronate can be quickly killed by $\mathrm{V} \delta 2 \mathrm{~V} \gamma 9 \mathrm{~T}$ cells in vitro [84]. A combination of chemotherapeutic drugs, zoledronic acid and $\mathrm{V} \delta 2 \mathrm{~V} \gamma 9 \mathrm{~T}$ cells has shown promising results in clinical trials [84]. In addition to $\mathrm{V} \delta 2 \mathrm{~V} \gamma 9 \mathrm{~T}$ cells, research focused on V81T cells has also showed promising results [85]. Afonso et al. in 2016 [86] defined a V81-enriched $(>60 \%)$ and NKG2D-upexpressing cytotoxic cell type, namely DOT cells. By designing a two-step method with distinct IL-4 expansion and IL-15 differentiation stages, a large number of (>2500-fold) DOT cells can be amplified in vitro to show special cytotoxicity against the MEC-1 cell of chronic lymphocytic leukemia, but not healthy autologous leukocytes [86].

Autologous chimeric antigen receptor (CAR)-T cell therapy has emerged as a star component of tumor immunotherapy in recent years. Specifically, CAR-T cell therapy has remarkable efficacy in the treatment of hematological tumors [87]. In spite of this success, CAR-T cell therapy based on $\alpha \beta T$ cells has not yet achieved a breakthrough in the treatment of solid tumors. The application space of CAR-T therapy is also limited by difficulty in applying the therapy in allogeneic cells. $\gamma \delta$ T cells make it possible to use allogenic CAR-T cells from donors due to their MHC-independent characteristics, and this method may be more convenient and economical than existing methods [88]. Based on this assumption, Utrecht University have validated CAR-T cells expressing given $V \delta 2 \mathrm{~V} \gamma 9$ TCR clone 5 (TEG001) in condition of a good manufacturing practice [89]. These heterozygous T cells are called $\mathrm{T}$ cells engineered with defined $\gamma \delta \mathrm{TCRs}$ (TEGs) [90], and have undoubtedly brought light to this therapeutic idea. Corporation Lava is developing a type of bispecific antibody that connects cancer cells and $\gamma \delta \mathrm{T}$ cells separately, improving the precision of targeting and prevents immune silencing of $\gamma \delta \mathrm{T}$ cells [91]. In-depth research on butyrophilin has provided a very effective target for the development of small molecule drugs based on $\gamma \delta \mathrm{T}$ cell therapy [92].

\section{Conclusion}

Crosstalk between commensal bacteria and $\gamma \delta \mathrm{T}$ cells increases the complexity and uncertainty of the tumor immune microenvironment. During the initiation of the tumor, $\gamma \delta \mathrm{T}$ cells are triggered by bacteria and migrate to the effector sites. The function of the aggregated $\gamma \delta \mathrm{T}$ cell population is further amplified, and $\gamma \delta \mathrm{T}$ cells can directly kill tumor cells or indirectly inhibit tumor growth through receptor-ligand interactions. However, the presence of $\gamma \delta \mathrm{T} 17$ cells is an unfavorable factor, and the immunosuppressive state created by these cells allows cancer cells to escape immune surveillance.

At present, there is no definite relationship between the structure and functional subsets of $\gamma \delta \mathrm{T}$ cells. Both $V \delta 1$ and $\mathrm{V} \delta 2 \gamma \delta \mathrm{T}$ cells have potential use in immunotherapy against cancer. Reprogramming $\gamma \delta \mathrm{T}$ cells to transform towards an antitumor phenotype through precise regulation is a hot 
research topic. As an impressive candidate for adoptive cellular therapy, $\gamma \delta \mathrm{T}$ cells have broad therapeutic prospects.

\begin{abstract}
Abbreviations
AhRs: Aryl hydrocarbon receptors; apo A-I: Apolipoprotein A-I; BTN3A1: Butyrophilin 3A1; CAR: Chimeric antigen receptor; CCR: C-C motif chemokine receptor; CXCR: C-X-C chemokine receptor; DNAM-1: DNAX accessory molecule-1; E. coli: Escherichia coli; FasL: Factor associated suicide ligand; GF: Germ-free; GM-CSF: Granulocyte-macrophage colony-stimulating factor; HMBPP: (E)-4-hydroxy-3-methyl-but-2-enyl pyrophosphate; hMSH2: Human MutS homologue 2; HSPS: Heat shock proteins; ICAM-1: Intercellular adhesion molecule 1; IFN-y: Interferon-gamma; IL: Interleukin; IPP: Isopentenyl pyrophosphate; MHC: Major histocompatibility complex; MICA/B: MHC class I-related chains A/B; MyD88: Myeloid differentiation factor 88; NCR: Natural cytotoxicity receptor; NKG2D: Natural killer, group 2, member D; PAMPs: Pathogen-associated molecular patterns; PMN-MDSCs: Polymorphonuclear myeloid-derived suppressor cells; RORyt: Acid-related orphan nuclear receptor gamma t; SPF: Specific pathogen-free; STAT3: Signal transducer and activator of transcription 3; TANs: Tumor-associated neutrophils; TGF: Transforming growth factors; TLRs: Toll-like receptors; TME: Tumor microenvironment; TNF-a: Tumor necrosis factor alpha; TRAIL: TNF-related apoptosis-inducing ligand; TRIF: TIR-domaincontaining adaptor inducing interferon- $\beta$; ULBP: UL16-binding proteins; VAV1: Vav guanine nucleotide exchange factor 1; VEGF: Vascular endothelial growth factor; $\gamma \delta T-A P C s: \gamma \delta T$ cells with antigen presentation function; $\gamma \delta T h 1$ : Helper $\gamma \delta T 1 ; \gamma \delta$ Treg: Regulatory $\gamma \delta T$.
\end{abstract}

\section{Acknowledgements}

Not applicable.

\section{Authors' contributions}

YTL and HS designed and drafted the manuscript; YH and SZ wrote figure legends and revised the article; YTL and YH drew the figures. All authors read and approved the final manuscript.

\section{Funding}

This work was supported by the National Natural Science Foundation of China (No. 81070362, 81172470, 81372629, 81772627, 81874073 \& 81974384); National Key R \& D Program of China (No. 2018YFC1313300); two key projects from the Nature Science Foundation of Hunan Province (No. 2015JC3021 \& 2016JC2037); and a project from China Cancer Elite Team Innovative Grant (No. 201606).

\section{Availability of data and materials}

Not applicable.

Ethics approval and consent to participate

Not applicable.

\section{Consent for publication}

Not applicable.

\section{Competing interests}

The authors declare that they have no competing interests.

\section{Author details}

${ }^{1}$ Department of Oncology, Xiangya Hospital, Central South University, Changsha 410008, Hunan, China. ${ }^{2}$ National Clinical Research Center for Geriatric Disorders, Xiangya Hospital, Central South University, Changsha 410008, Hunan, P.R. China. ${ }^{3}$ Key Laboratory for Molecular Radiation Oncology of Hunan Province, Xiangya Hospital, Central South University, Changsha 410008, Hunan, China.

Received: 22 October 2020 Accepted: 23 February 2021

Published online: 02 March 2021

\section{References}

1. Brestoff JR, Artis D. Commensal bacteria at the interface of host metabolism and the immune system. Nat Immunol. 2013;14(7):676-84.

2. Nejman D, Livyatan I, Fuks G, Gavert N, Zwang Y, Geller L, et al. The human tumor microbiome is composed of tumor type-specific intracellular bacteria. Science (New York, NY). 2020;368(6494):973-80.

3. Bhatt $\mathrm{A}$, Redinbo M, Bultman S. The role of the microbiome in cancer development and therapy. CA Cancer J Clin. 2017;67(4):326-44.

4. Chen J, Domingue J, Sears C. Microbiota dysbiosis in select human cancers: Evidence of association and causality. Semin Immunol. 2017:32:25-34

5. Jenkins SV, Robeson MS, Griffin RJ, Quick CM, Siegel ER, Cannon MJ, et al. Gastrointestinal tract dysbiosis enhances distal tumor progression through suppression of leukocyte trafficking. Cancer Res. 2019;79(23):5999-6009.

6. Lida N, Dzutsev A, Stewart CA, Smith L, Bouladoux N, Weingarten RA, et al. Commensal bacteria control cancer response to therapy by modulating the tumor microenvironment. Science (New York, NY). 2013;342(6161):967-70.

7. Viaud S, Saccheri F, Mignot G, Yamazaki T, Daillère R, Hannani D, et al. The intestinal microbiota modulates the anticancer immune effects of cyclophosphamide. Science (New York, NY). 2013;342(6161):971-6.

8. Gopalakrishnan V, Spencer C, Nezi L, Reuben A, Andrews M, Karpinets T, et al. Gut microbiome modulates response to anti-PD-1 immunotherapy in melanoma patients. Science (New York, NY). 2018;359(6371):97-103.

9. Tanoue T, Morita S, Plichta D, Skelly A, Suda W, Sugiura Y, et al. A defined commensal consortium elicits CD8 T cells and anti-cancer immunity. Nature. 2019;565(7741):600-5.

10. Chien YH, Meyer C, Bonneville M. $\gamma \delta T$ cells: first line of defense and beyond. Ann Rev Immunol. 2014;32:121-55.

11. Bonneville M, O'Brien R, Born W. Gammadelta T cell effector functions: a blend of innate programming and acquired plasticity. Nat Rev Immunol. 2010;10(7):467-78.

12. Silva-Santos $B$, Serre $K$, Norell $H$. $\gamma \delta$ T cells in cancer. Nat Rev Immunol. 2015:15(11):683-91.

13. Vantourout $P$, Hayday A. Six-of-the-best: unique contributions of gammadelta T cells to immunology. Nat Rev Immunol. 2013;13(2):88-100.

14. Heilig J, Tonegawa S. Diversity of murine gamma genes and expression in fetal and adult T lymphocytes. Nature. 1986;322(6082):836-40.

15. Wu D, Wu P, Qiu F, Wei Q, Huang J. Human $\gamma \delta T$-cell subsets and their involvement in tumor immunity. Cell Mol Immunol. 2017;14(3):245-53.

16. Li M, Wang B, Sun $X$, Tang $Y$, Wei $X$, Ge B, et al. Upregulation of intestinal barrier function in mice with DSS-induced colitis by a defined bacterial consortium is associated with expansion of IL-17A producing gamma delta T cells. Front Immunol. 2017;8:824

17. Zhou QH, Wu FT, Pang LT, Zhang TB, Chen Z. Role of gammadeltaT cells in liver diseases and its relationship with intestinal microbiota. World J Gastroenterol. 2020;26(20):2559-69.

18. Zhao H, Nguyen $\mathrm{H}$, Kang J. Interleukin 15 controls the generation of the restricted $T$ cell receptor repertoire of gamma delta intestinal intraepithelial lymphocytes. Nat Immunol. 2005;6(12):1263-71.

19. Li F, Hao X, Chen Y, Bai L, Gao X, Lian Z, et al. The microbiota maintain homeostasis of liver-resident $\gamma \delta T-17$ cells in a lipid antigen/CD1ddependent manner. Nat Commun. 2017;7:13839.

20. Duan J, Chung H, Troy E, Kasper DL. Microbial colonization drives expansion of IL-1 receptor 1-expressing and IL-17-producing gamma/delta T cells. Cell Host Microbe. 2010;7(2):140-50.

21. Hedges J, Lubick K, Jutila M. Gamma delta T cells respond directly to pathogen-associated molecular patterns. J Immunol. 2005;174(10):6045-53.

22. Dar A, Patil R, Chiplunkar S. Insights into the relationship between toll like receptors and gamma delta T cell responses. Front Immunol. 2014;5:366.

23. Zhang S, Jouanguy E, Ugolini S, Smahi A, Elain G, Romero P, et al. TLR3 deficiency in patients with herpes simplex encephalitis. Science (New York, NY). 2007;317(5844):1522-7.

24. Peng $G$, Wang $H$, Peng W, Kiniwa $Y$, Seo $K$, Wang R. Tumor-infiltrating gammadelta $T$ cells suppress $T$ and dendritic cell function via mechanisms controlled by a unique toll-like receptor signaling pathway. Immunity. 2007;27(2):334-48.

25. Luoma A, Castro C, Mayassi T, Bembinster L, Bai L, Picard D, et al. Crystal structure of $\mathrm{V} \delta 1 \mathrm{~T}$ cell receptor in complex with CD1d-sulfatide shows 
MHC-like recognition of a self-lipid by human $\gamma \delta T$ cells. Immunity. 2013;39(6):1032-42.

26. Luoma A, Castro C, Adams E. $\gamma \delta$ T cell surveillance via CD1 molecules. Trends Immunol. 2014;35(12):613-21.

27. Li F, Hao X, Chen Y, Bai L, Gao X, Lian Z, et al. The microbiota maintain homeostasis of liver-resident $Y \delta T-17$ cells in a lipid antigen/CD1ddependent manner. Nat Commun. 2017:8(1):1-5.

28. Morita C, Jin C, Sarikonda G, Wang H. Nonpeptide antigens, presentation mechanisms, and immunological memory of human Vgamma2Vdelta2 $T$ cells: discriminating friend from foe through the recognition of prenyl pyrophosphate antigens. Immunol Rev. 2007;215:59-76.

29. Xiang Z, Tu W. Dual face of VY9V $22-T$ cells in tumor immunology: antiversus pro-tumoral activities. Front Immunol. 2017:8:1041.

30. Yang Y, Li L, Yuan L, Zhou X, Duan J, Xiao H, et al. A structural change in butyrophilin upon phosphoantigen binding underlies phosphoantigenmediated VY9V82T cell activation. Immunity. 2019;50(4):1043-53.e5.

31. Wang H, Nada M, Tanaka Y, Sakuraba S, Morita C. Critical roles for coiledcoil dimers of butyrophilin $3 \mathrm{~A} 1$ in the sensing of prenyl pyrophosphates by human Vy2V 22 T cells. J Immunol. 2019;203(3):607-26.

32. Hoytema van Konijnenburg D, Reis B, Pedicord V, Farache J, Victora G, Mucida D. Intestinal epithelial and intraepithelial T cell crosstalk mediates a dynamic response to infection. Cell. 2017;171(4):783-94.e13.

33. Edelblum K, Shen L, Weber C, Marchiando A, Clay B, Wang Y, et al. Dynamic migration of $\gamma \delta$ intraepithelial lymphocytes requires occludin. Proc Natl Acad Sci USA. 2012;109(18):7097-102.

34. Edelblum K, Singh G, Odenwald M, Lingaraju A, El Bissati K, McLeod $\mathrm{R}$, et al. $\gamma \delta$ intraepithelial lymphocyte migration limits transepithelial pathogen invasion and systemic disease in mice. Gastroenterology. 2015;148(7):1417-26.

35. Hu M, Ethridge A, Lipstein R, Kumar S, Wang Y, Jabri B, et al. Epithelial IL-15 is a critical regulator of $\gamma \delta$ intraepithelial lymphocyte motility within the intestinal mucosa. J Immunol. 2018;201(2):747-56.

36. Park J, Kotani T, Konno T, Setiawan J, Kitamura Y, Imada S, et al. Promotion of intestinal epithelial cell turnover by commensal bacteria: role of shortchain fatty acids. PLoS ONE. 2016;11(5):e0156334.

37. Brandes M, Willimann K, Lang A, Nam K, Jin C, Brenner M, et al. Flexible migration program regulates gamma delta T-cell involvement in humoral immunity. Blood. 2003;102(10):3693-701.

38. Wu D, Wu P, Qiu F, Wei Q, Huang J. Human gammadeltaT-cell subsets and their involvement in tumor immunity. Cell Mol Immunol. 2017;14(3):245-53.

39. Yang $B$, Kang $H$, Fung $A$, Zhao $H$, Wang T, Ma D. The role of interleukin 17 in tumour proliferation, angiogenesis, and metastasis. Mediators Inflamm. 2014;2014:1-12.

40. Kuen DS, Kim BS, Chung Y. IL-17-producing cells in tumor immunity: friends or foes? Immune Netw. 2020:20(1):e6.

41. O'Brien R, Born W. Two functionally distinct subsets of IL-17 producing $\gamma \delta$ T cells. Immunol Rev. 2020;298(1):10-24.

42. Jensen K, Su X, Shin S, Li L, Youssef S, Yamasaki S, et al. Thymic selection determines gammadelta $T$ cell effector fate: antigen-naive cells make interleukin-17 and antigen-experienced cells make interferon gamma. Immunity. 2008;29(1):90-100.

43. Grivennikov S, Wang K, Mucida D, Stewart C, Schnabl B, Jauch D, et al. Adenoma-linked barrier defects and microbial products drive IL-23/L17-mediated tumour growth. Nature. 2012;491(7423):254-8.

44. Wang K, Karin M. The IL-23 to IL-17 cascade inflammation-related cancers. Clin Exp Rheumatol. 2015;33:587-90.

45. Rei M, Gonçalves-Sousa N, Lança T, Thompson R, Mensurado S, Balkwill F, et al. Murine CD27(-) Vy6(+) $\gamma \delta$ T cells producing IL-17A promote ovarian cancer growth via mobilization of protumor small peritoneal macrophages. Proc Natl Acad Sci USA. 2014;111(34):E3562-70.

46. Patin E, Soulard D, Fleury S, Hassane M, Dombrowicz D, Faveeuw C, et al. Type I IFN receptor signaling controls IL7-dependent accumulation and activity of protumoral IL17A-producing $\gamma \delta T$ cells in breast cancer. Can Res. 2018;78(1):195-204.

47. Michel M, Pang D, Haque S, Potocnik A, Pennington D, Hayday A. Interleukin 7 (IL-7) selectively promotes mouse and human IL-17-producing $\gamma \delta$ cells. Proc Natl Acad Sci USA. 2012;109(43):17549-54.

48. Lee JS, Tato CM, Joyce-Shaikh B, Gulen MF, Cayatte C, Chen Y, et al. Interleukin-23-Independent IL-17 production regulates intestinal epithelial permeability. Immunity. 2015;43(4):727-38.
49. Sakaguchi $\mathrm{S}$. Naturally arising Foxp3-expressing $\mathrm{CD} 25+\mathrm{CD} 4+$ regulatory T cells in immunological tolerance to self and non-self. Nat Immunol. 2005;6(4):345-52.

50. Casetti R, Agrati C, Wallace M, Sacchi A, Martini F, Martino A, et al. Cutting edge: TGF-beta1 and IL-15 Induce FOXP3+ gammadelta regulatory T cells in the presence of antigen stimulation. J Immunol. 2009;183(6):3574-7.

51. Ribot J, Ribeiro S, Correia D, Sousa A, Silva-Santos B. Human $\gamma \delta$ thymocytes are functionally immature and differentiate into cytotoxic type 1 effector T cells upon IL-2/IL-15 signaling. J Immunol. 2014;192(5):2237-43.

52. Van Acker $H$, Anguille $S$, Willemen $Y$, Van den Bergh J, Berneman Z, Lion $\mathrm{E}$, et al. Interleukin-15 enhances the proliferation, stimulatory phenotype, and antitumor effector functions of human gamma delta T cells. J Hematol Oncol. 2016;9(1):101.

53. Gentles A, Newman A, Liu C, Bratman S, Feng W, Kim D, et al. The prognostic landscape of genes and infiltrating immune cells across human cancers. Nat Med. 2015;21(8):938-45.

54. Morisaki T, Onishi H, Katano M. Cancer immunotherapy using NKG2D and DNAM-1 systems. Anticancer Res. 2012;32(6):2241-7.

55. Wrobel P, Shojaei H, Schittek B, Gieseler F, Wollenberg B, Kalthoff H, et al. Lysis of a broad range of epithelial tumour cells by human gamma delta T cells: involvement of NKG2D ligands and T-cell receptor- versus NKG2Ddependent recognition. Scand J Immunol. 2007;66:320-8.

56. Wu D, Wu P, Wu X, Ye J, Wang Z, Zhao S, et al. Ex vivo expanded human circulating V $\delta 1 \gamma \delta T$ cells exhibit favorable therapeutic potential for colon cancer. Oncoimmunology. 2015;4(3):e992749.

57. Lança T, Correia D, Moita C, Raquel H, Neves-Costa A, Ferreira C, et al. The MHC class Ib protein ULBP1 is a nonredundant determinant of leukemia/ lymphoma susceptibility to gammadelta T-cell cytotoxicity. Blood. 2010:115(12):2407-11.

58. Mikulak J, Oriolo F, Bruni E, Roberto A, Colombo F, Villa A, et al. NKp46expressing human gut-resident intraepithelial V $\delta 1 \mathrm{~T}$ cell subpopulation exhibits high antitumor activity against colorectal cancer. JCl insight. 2019:4(24):e125884.

59. Brandt C, Baratin M, Yi E, Kennedy J, Gao Z, Fox B, et al. The B7 family member B7-H6 is a tumor cell ligand for the activating natural killer cell receptor NKp30 in humans. J Exp Med. 2009;206(7):1495-503.

60. Chen Y, Mo J, Jia X, He Y. The B7 family member B7-H6: a new bane of tumor. Pathol Oncol Res POR. 2018;24(4):717-21.

61. Scotet $E$, Martinez $L$, Grant E, Barbaras R, Jenö $P$, Guiraud M, et al. Tumor recognition following Vgamma9Vdelta2 $T$ cell receptor interactions with a surface F1-ATPase-related structure and apolipoprotein A-I. Immunity. 2005;22(1):71-80.

62. Marlin R, Pappalardo A, Kaminski H, Willcox C, Pitard V, Netzer S, et al. Sensing of cell stress by human $\gamma \delta$ TCR-dependent recognition of annexin A2. Proc Natl Acad Sci USA. 2017;114(12):3163-8.

63. Sharma M. Annexin A2 (ANX A2): An emerging biomarker and potential therapeutic target for aggressive cancers. Int I Cancer. 2019;144(9):2074-81.

64. Dai Y, Chen H, Mo C, Cui L, He W. Ectopically expressed human tumor biomarker MutS homologue 2 is a novel endogenous ligand that is recognized by human $\gamma \delta T$ cells to induce innate anti-tumor/virus immunity. J Biol Chem. 2012;287(20):16812-9.

65. Lança T, Costa M, Gonçalves-Sousa N, Rei M, Grosso A, Penido C, et al. Protective role of the inflammatory CCR2/CCL2 chemokine pathway through recruitment of type 1 cytotoxic $\gamma \delta$ T lymphocytes to tumor beds. J Immunol. 2013;190(12):6673-80.

66. Kenna T, Golden-Mason L, Norris S, Hegarty J, O'Farrelly C, Doherty D. Distinct subpopulations of gamma delta T cells are present in normal and tumor-bearing human liver. Clin Immunol. 2004;113(1):56-63.

67. Brandes M, Willimann K, Moser B. Professional antigen-presentation function by human gammadelta T Cells. Science (New York, NY). 2005;309(5732):264-8.

68. Tyler C, McCarthy N, Lindsay J, Stagg A, Moser B, Eberl M. Antigen-presenting human $\gamma \delta$ T cells promote intestinal CD4 T cell expression of IL-22 and mucosal release of calprotectin. J Immunol. 2017;198(9):3417-25.

69. Lo Presti E, Toia F, Oieni S, Buccheri S, Turdo A, Mangiapane L, et al Squamous cell tumors recruit $\gamma \delta$ T cells producing either IL 17 or IFNY depending on the tumor stage. Cancer Immunol Res. 2017:5(5):397-407.

70. Wu P, Wu D, Ni C, Ye J, Chen W, Hu G, et al. үסT17 cells promote the accumulation and expansion of myeloid-derived suppressor cells in human colorectal cancer. Immunity. 2014;40(5):785-800. 
71. Ma C, Zhang Q, Ye J, Wang F, Zhang Y, Wevers E, et al. Tumor-infiltrating

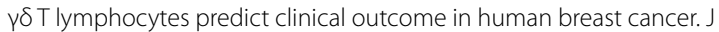
Immunol. 2012;189(10):5029-36.

72. Jin C, Lagoudas G, Zhao C, Bullman S, Bhutkar A, Hu B, et al. Commensal microbiota promote lung cancer development via $ү \delta T$ Cells. Cell. 2019;176(5):998-1013.e16.

73. Yu H, Jove R. The STATs of cancer-new molecular targets come of age. Nat Rev Cancer. 2004;4(2):97-105.

74. Fan Y, Mao R, Yang J. NF-KB and STAT3 signaling pathways collaboratively link inflammation to cancer. Protein Cell. 2013;4(3):176-85.

75. Coffelt S, Kersten K, Doornebal C, Weiden J, Vrijland K, Hau C, et al. IL-17-producing $\gamma \delta T$ cells and neutrophils conspire to promote breast cancer metastasis. Nature. 2015;522(7556):345-8.

76. Chen Y, Zhao Z, Chen Y, Lv Z, Ding X, Wang R, et al. An epithelial-to-mesenchymal transition-inducing potential of granulocyte macrophage colony-stimulating factor in colon cancer. Scientific reports. 2017;7(1):8265.

77. Yan J, Huang J. Innate $\gamma \delta T 17$ cells convert cancer-elicited inflammation into immunosuppression through myeloid-derived suppressor cells. Oncoimmunology. 2014;3(8):e953423.

78. Liu J, Duan Y, Cheng X, Chen X, Xie W, Long H, et al. IL-17 is associated with poor prognosis and promotes angiogenesis via stimulating VEGF production of cancer cells in colorectal carcinoma. Biochem Biophys Res Commun. 2011;407(2):348-54.

79. Patil R, Shah S, Shrikhande S, Goel M, Dikshit R, Chiplunkar S. IL17 producing $\gamma \delta T$ cells induce angiogenesis and are associated with poor survival in gallbladder cancer patients. Int J Cancer. 2016;139(4):869-81.

80. Hu G, Wu P, Cheng P, Zhang Z, Wang Z, Yu X, et al. Tumor-infiltrating CD39Tregs are novel immunosuppressive T cells in human colorectal cancer. Oncoimmunology. 2017:6(2):e1277305.

81. Sugai S, Yoshikawa T, Iwama T, Tsuchiya N, Ueda N, Fujinami N, et al. Hepatocellular carcinoma cell sensitivity to Vgamma9Vdelta2 T lymphocyte-mediated killing is increased by zoledronate. Int J Oncol. 2016:48(5):1794-804.

82. Kondo M, Izumi T, Fujieda N, Kondo A, Morishita T, Matsushita H, et al. Expansion of human peripheral blood $\gamma \delta T$ cells using zoledronate. J Vis Exp. 2011;55:3182.
83. Nishio N, Fujita M, Tanaka Y, Maki H, Zhang R, Hirosawa T, et al. Zoledronate sensitizes neuroblastoma-derived tumor-initiating cells to cytolysis mediated by human $\gamma \delta$ T cells. J Immunother. 2012;35(8):598-606.

84. Mattarollo S, Kenna T, Nieda M, Nicol A. Chemotherapy and zoledronate sensitize solid tumour cells to Vgamma9Vdelta2 T cell cytotoxicity. Cancer Immunol Immunother. 2007;56(8):1285-97.

85. Siegers G, Dhamko H, Wang X, Mathieson A, Kosaka Y, Felizardo T, et al. Human V $\delta 1 \gamma \delta T$ cells expanded from peripheral blood exhibit specific cytotoxicity against B-cell chronic lymphocytic leukemia-derived cells. Cytotherapy. 2011;13(6):753-64.

86. Almeida A, Correia D, Fernandes-Platzgummer A, da Silva C, da Silva M, Anjos D, et al. Delta one T cells for immunotherapy of chronic lymphocytic leukemia: clinical-grade expansion/differentiation and preclinical proof of concept. Clin Cancer Res. 2016;22(23):5795-804.

87. Singh A, McGuirk J. CART cells: continuation in a revolution of immunotherapy. Lancet Oncol. 2020;21(3):e168-78.

88. Depil S, Duchateau P, Grupp S, Mufti G, Poirot L. "Off-the-shelf" allogeneic CART cells: development and challenges. Nat Rev Drug Discov. 2020;19(3):185-99.

89. Straetemans T, Kierkels G, Doorn R, Jansen K, Heijhuurs S, Dos Santos J, et al. GMP-grade manufacturing of T cells engineered to express a defined үठTCR. Front Immunol. 2018;9:1062

90. Marcu-Malina V, Heijhuurs S, van Buuren M, Hartkamp L, Strand S, Sebestyen $Z$, et al. Redirecting a $\mathrm{T} T$ cells against cancer cells by transfer of a broadly tumor-reactive $\gamma \delta T$-cell receptor. Blood. 2011;118(1):50-9.

91. Labrijn A, Janmaat M, Reichert J, Parren P. Bispecific antibodies: a mechanistic review of the pipeline. Nat Rev Drug Discov. 2019;18(8):585-608.

92. Vavassori S, Kumar A, Wan G, Ramanjaneyulu G, Cavallari M, El Daker S, et al. Butyrophilin 3A1 binds phosphorylated antigens and stimulates human $\gamma \delta$ T cells. Nat Immunol. 2013;14(9):908-16.

\section{Publisher's Note}

Springer Nature remains neutral with regard to jurisdictional claims in published maps and institutional affiliations.
Ready to submit your research? Choose BMC and benefit from:

- fast, convenient online submission

- thorough peer review by experienced researchers in your field

- rapid publication on acceptance

- support for research data, including large and complex data types

- gold Open Access which fosters wider collaboration and increased citations

- maximum visibility for your research: over $100 \mathrm{M}$ website views per year

At BMC, research is always in progress.

Learn more biomedcentral.com/submissions 